Jon Magne Vestøl

Universitetet i Oslo

Anne Kristin Dahl

Universitetet i Oslo

Tove Seiness Hunskaar

Universitetet i Oslo

DOI: http://dx.doi.org/10.5617/adno.4447

\title{
Kunnskapsintegrasjon i praksis. \\ Samvirke mellom kunnskapsområder i lektorstudenters undervisningspraksis og refleksjon
}

\section{Sammendrag}

Denne artikkelen undersøker hvordan kunnskapsområder samvirker i lektorstudenters undervisningspraksis og refleksjon over praksis. Hensikten med studien har vcert å få en nyansert forståelse av hvordan kunnskapsintegrasjon framtrer $i$ noen studenters praksisutøvelse og praksisrefleksjon. Artikkelen bygger på intervjuer med lektorstudenter og deres veiledere og observasjon av lektorstudenters undervisning og tilhørende før- og etterveiledning. Studien viser hvordan studenter utøver kunnskapsintegrasjon i interaksjon med elever og veiledere og hvordan de søker forankring for kunnskapsintegrasjon i pedagogiske perspektiver eller håndverkstradisjon.

Nøkkelord: lærerutdanning, kunnskapsintegrasjon, koherens, praksiskunnskap, fagkunnskap, profesjonskunnskap

Knowledge intergration in internship.

Interaction between knowledge domains in student teachers' teaching and reflection

\begin{abstract}
This study investigates how knowledge domains interact in student teachers' teaching and reflection during internship. The aim of the study has been to provide a nuanced understanding of how knowledge integration emerges in some students' teaching performance and reflection on their own teaching practice. Drawing on observations of classroom teaching and supervision as well as interviews with student teachers and their supervisors, the study demonstrates how knowledge integration takes place through interaction with pupils and
\end{abstract}


supervisors, and how student teachers anchor their knowledge integration in pedagogical perspectives or in an understanding of teaching as craftsmanship.

Keywords: teacher education, knowledge integration, coherence, practical knowledge, content knowledge, professional knowledge

\section{Innledning}

Utviklingen av femårige integrerte lektorutdanninger har økt fokuset på hvordan kunnskapsfelt samvirker i studentenes kompetanseutvikling (KD, 2013). Internasjonal litteratur drøfter spørsmål knyttet til kunnskapsformer og koherens mellom kunnskapsfelt i lærerutdanning (Cochran-Smith \& Lytle, 1999; Eraut, 2004; Fenstermacher, 1994; Grossmann, Hammerness, McDonald \& Ronfeldt, 2008; Hammerness, 2006; Heggen \& Smeby, 2012). Flere norske studier har pekt på mangelfullt samvirke mellom campusundervisning og praksis (Fosse, 2011, 2016; Fosse \& Hovdenak, 2014; Jahreie \& Ottesen, 2010; Ottesen, 2006). Det er likevel sparsomt med forskning som retter seg mer spesifikt mot fenomenet kunnskapsintegrasjon forstått som samvirke mellom kunnskapsområder (Granlund, 2013; Vestøl, 2014). Vi har derfor ønsket å gjøre en studie over følgende problemstilling: Hvordan samvirker kunnskapsområder i lektorstudenters praksisrefleksjon og praksisutøvelse?

\section{Begreper og perspektiver}

Begrepet integrasjon betegner gjerne en sammenslutning av enheter til en større eller mer enhetlig struktur (Schneider, 2012). I vår artikkel brukes begrepene «integrasjon» og «samvirke» synonymt for å betegne samspill og brytninger mellom elementer fra ulike kunnskapsfelt. Heggen og Smeby (2012) sidestiller «integrasjon», «samanheng» og «koherens». Integrasjon og koherens brukes generelt om både makro- og mikronivå, men vår studie fokuserer på mikronivået. Bernstein (1975) bruker begrepet integrasjon for å beskrive organisering av kunnskapsfelt i utdanningssystemer og skjelner mellom en kolleksjonskode hvor kunnskapsinnhold er avgrenset og atskilt, og en integrasjonskode hvor kunnskapstilfang står i en åpen relasjon til hverandre. Integrasjonskoden er betinget av en overgripende idé som er knyttet til prinsipper på høyt abstraksjonsnivå og som også berører dypstruktur og kunnskapsmodi. I vår studie vil en eventuell integrasjonskode kunne tre fram i studenters beskrivelser av studiedesign.

I en tidligere studie (Vestøl, 2016) er integrasjon beskrevet som samspill på ulike nivåer (Cole, 1996; Daniels, 2001; Engeström, 1987; Wartofsky, 1973/ 1979). Wartofsky (1973/1979) skjelner mellom primære, sekundære og tertiære artefakter. Primcere artefakter er fysiske eller språklige redskaper for handling og meningsskaping. Sekundcere artefakter er en kombinasjon av primære artef- 
akter og tilknyttede rammer for handling i form av konvensjoner, forestillinger og normer. Terticere artefakter er imaginære forestillingsverdener som har en viss uavhengighet og har evne til å endre aktørers persepsjon av virkelighet, og består av eksempelvis narrativer, teorier og modeller. Engeström (1987) skjelner på lignende måte mellom tre nivåer av læring, med nivå 1 som tilfang av kunnskapselementer, et nivå 2 som en sammenstilling av slike elementer, og et ekspansivt nivå 3 som overskrider eksisterende rammebetingelser. I begge perspektiver står mellomnivået for en konvensjonell integrasjon, mens man på øvre nivå overskrider konvensjonelle rammer.

Begrepet integrasjon brukes til dels synonymt med koherens (Heggen \& Smeby, 2012), og internasjonalt synes koherens («coherence») å være mest brukt (Grossmann et al., 2008). Begrepsmessig koherens betegner sentrale ideer og felles visjoner, og strukturell koherens omfatter logistikk og design (Grossmann et al., 2008; Hammerness, 2006). Det diskuteres om grad av koherens er et mål på kvalitet og om hvorvidt koherens innebærer en full konsistens eller kan romme spenning og konflikt mellom kunnskapsformer (Buchmann \& Floden, 1992; Grossmann et al., 2008). Heggen og Smeby (2012) utfordrer det å gjøre koherens til premiss for utdanningspolitikk og forskning, og de framhever former for koherens som biografisk koherens knyttet til personlige forutsetninger, og overgangskoherens som handler om sammenheng mellom lærerutdanning og yrke. De hevder at læring ikke er spenningsfri og konfliktløs, og poengterer også at teoretisk kunnskap i seg selv er viktig for studentens utvikling. Heggen og Raaen (2014) peker også på koherens som forening av det konserverende i eksisterende praksiser og det dynamiske ved ny og utfordrende kunnskap.

\section{Tidligere empirisk forskning}

Forskning på kunnskapsintegrasjon har ifølge Schneider (2012) og Haugan (2011) primært fokusert på fagområder som naturvitenskap og matematikk og på bruk av IKT. Ifølge Schneider (2012) synes kunnskapsintegrasjon å fremmes når synspunkter brytes og blir tydeliggjort, og når nye perspektiver utfordrer til å revidere og evaluere eksisterende oppfatninger. Vestøl (2014) har undersøkt kunnskapsintegrasjon i eksamenstekster fra lektorstudenter og vist at kunnskapselementer fra ulike fagfelt kan samspille i studenttekster, med ulike tyngdepunkt og formål. I noen tekster ble et faglig begrep eller fenomen fulgt inn i møte med fagdidaktikk og pedagogikk og praksis, mens andre tekster fulgte et praksisfenomen inn i møte med et fagtema. I enkelte tekster var samvirket mer tentativt og eksplorerende. Granlund (2013) undersøkte lærerutdanning på institusjonsnivå i lys av Bernstein, og fant ulike typer integrasjonskoder som var knyttet til anti-autoritær reformpedagogikk som overordnet idé. Forskning på koherens har vist at norske lærerutdanninger har svak begrepskoherens og strukturkoherens (Hammerness, 2013), og at praksisperspektivet får noe varierende rom i undervisningen (Jenset, Klette \& Hammerness, 2018; Klette \& Hammerness, 2016). 
Forholdet mellom campusundervisning og praksis i norsk lærerutdanning er behandlet i flere studier (se Fosse, 2016), blant annet fra Universitetet i Oslo (Fosse, 2011; Fosse \& Hovdenak, 2014; Jahreie \& Ottesen, 2010; Ottesen, 2006). Ottesen (2006) pekte på at lærerstudenter søkte løsninger basert på praksiskonvensjoner, og Fosse (2011) at studentene hadde et lite reflektert analytisk forhold til praksis. Ifølge Fosse og Hovdenak (2014) vektla studenter kunnskap som techne, og ifølge Jahreie og Ottesen (2010) fokuserte studenter på «procedural actions» (s. 231). En Nokut-undersøkelse pekte på at PPU-studenter var kritiske til teoriperspektiver, men at de likevel savnet slike perspektiver for å løse praktiske utfordringer (Lid, 2013).

Studier av praksisveiledning for grunnskolelærerstudenter har pekt på at allmenndidaktikk dominerer over fag (Østrem, 2016), og på svak sammenheng mellom forskning og praksis (Haugan, 2014; Haugan, Moen \& Karlsdottir, 2013). Men ifølge Haugan (2014) viste studenter i intervjuer og skriftlige refleksjoner at de kunne forankre valg i overordnede mål og i noen grad bruke teoretiske artefakter. Studier har også sett på betydningen av veiledning (Bjerkholt, 2013; Jensen, 2016; Lejonberg, 2016) og styrking av rammeforhold for praksis gjennom partnerskap mellom UHR-institusjoner og praksisskoler (Lejonberg, Elstad \& Hunskaar, 2017; Lillejord \& Børte, 2014; Rindal, Lund \& Jakhelln, 2015).

Ut fra kunnskapsstatusen på feltet mener vi det er behov for en eksplorerende undersøkelse av kunnskapsintegrasjon i lektorstudenters praksisundervisning. Vi har lagt til grunn en pragmatisk forståelse av «kunnskapsområder» ved å ta utgangspunkt i studieprogrammet informantene fulgte. «Fagkunnskap» er derfor forstått som disiplinfagene norsk og engelsk i lektorstudiet og «profesjonskunnskap» er fagdidaktikk og pedagogikk i studiets profesjonsemner. Selv om profesjonsemnene også har praksis som komponent, beskriver vi «praksiskunnskap» som et eget område fordi praksis er lagt til en egen institusjon - praksisskolen og er underlagt andre aktører og premisser enn campusdelen av profesjonsfaget.

\section{Metode}

Studien er kvalitativ og eksplorerende med et begrenset datatilfang. Vi fulgte tre lektorstudenter i veiledet undervisningspraksis med oppfølgende intervju høsten 2014. Studentene var i 7. semester av et «integrert» lektorprogram ved UiO og hadde praksis ved to videregående skoler, student «Andreas» på skole $\mathrm{A}$ og studentene «Birger» og «Birgitte» sammen på skole B (Tabell 1). I faget norsk (skole A) var temaet retorisk analyse (jf. Bakken, 2009), mens tema i faget engelsk (skole B) var personkarakteristikk i litteratur og film og bruk av muntlig engelsk (jf. Simensen, 2007). I profesjonsfaget på campus inngikk seminarer og studielitteratur i fagdidaktikk og pedagogikk, med perspektiver fra eksempelvis Vygotsky (Bråten \& Thurman-Moe, 1998). 
I begge klassene ble elevene introdusert for fagbegreper som de brukte for å analysere et leserinnlegg (skole A) (Letelier, 2014) eller en filmatisert roman (skole B) (Chbosky, 2012). Elevene jobbet individuelt og i smågrupper (skole A) eller i flere runder med «speed date», det vil si korte, parvise samtaler, (skole B) før en avsluttende oppsummering i plenum.

Tabell 1. Informanter og fag

\begin{tabular}{|l|l|l|}
\hline \multicolumn{2}{|l|}{ Skole A } & Skole B \\
\hline Studenter & «Andreas» & «Birgitte» og «Birger» \\
\hline Veileder & «Anette» & «Brian» \\
\hline Fag & Norsk & Engelsk \\
\hline Elever & 30 & 30 \\
\hline Intervju & Student (85 min), Veileder (83 min) & Studenter (75 min), Veileder (93 min) \\
\hline Observasjon & Førveiledning (51 min) & Førveiledning (83 min) \\
& Undervisning (90 min) & Undervisning (Birgitte: 90 min + Birger: 145 min) \\
& Etterveiledning (52 min) & Etterveiledning (30 min + 28 min) \\
\hline
\end{tabular}

Det ble gjort lyd- og videoopptak av intervjuer, veiledning og undervisning. Prosjektet ble meldt til NSD, og samtykke var gitt av alle informanter, inklusiv elever. Opptakene ble transkribert og anonymisert. Intervjuene fulgte en semistrukturert intervjuguide med vekt på fagkunnskap, praksiskunnskap og profesjonskunnskap. Analysen har lagt hovedvekten på studentenes ytringer, men veiledere og elever refereres når det er relevant for studentenes kunnskapsutvikling og refleksjon.

Analysen startet med en åpen koding av temaer. Deretter ble materialet kodet ut fra kunnskapsområdene fagkunnskap, praksiskunnskap og profesjonskunnskap som hovedkategorier. Det ble så foretatt en meningsfortetting der tekstpassasjer ble kondensert til konsise meningsenheter (Johannessen, Tufte \& Kristoffersen, 2006; Kvale \& Brinkmann, 2015). Passasjene ble systematisert til konsentrerte beskrivelser av de tre kunnskapsområdene (Figur 1, I-III). En lignende meningsfortetting ble gjort av tekstpassasjer som var knyttet til mer enn ett kunnskapsområde (Figur 1, A-C).

Med basis i dette ble det valgt ut tre handlingsforløp fra undervisning og veiledning som viser studentene $\mathrm{i}$ tre sentrale faser $\mathrm{i}$ læringsarbeidet: introduksjon av begreper (Eksempel 1), anvendelse av begreper (Eksempel 2) og oppsummering i plenum (Eksempel 3). Disse eksemplene kan forstås som kronologiske og hendelsesfokuserte beskrivelser slik det er vanlig i etnografisk forskning (Johannessen et al., 2006). Sekvensene konkretiserer samvirkeaspekter som er omtalt i Figur 1, A-C.

\section{Forståelsen av kunnskapsområdene i materialet}

Før vi presenterer samvirkeaspekter i materialet, gir vi riss av de tre kunnskapsområdene slik de trådte fram i materialet som helhet (Figur 1, I-III). 


\section{Fagkunnskap}

Fagkunnskapen i materialet (Figur 1, I) var akademisk kunnskap i retorikk og litteraturvitenskap knyttet til kompetanse- og ferdighetsmål i fagene norsk og engelsk. Kildene til fagkunnskap var fagemner, nettkilder og innspill fra veileder. Lektorstudentene brukte illustrerende eksempler for å konkretisere fagkunnskapen.

Studentenes forhold til fagkunnskap varierte fra det engasjerte og aktive (Andreas) til det mer distanserte (Birger), men forskjellene var ikke tydelige i undervisningen. Innramming og vinkling av fagkunnskapen tok hensyn til elevforutsetninger, blant annet gjennom valg av tekst- og filmeksempler. Kunnskapstilfanget var innpasset i undervisningsforløp som ledet fram mot en planlagt vurderingssituasjon.

\begin{tabular}{|c|c|c|}
\hline \multirow[b]{2}{*}{$\begin{array}{l}\text { I FAGKUNNSKAP } \\
1 \text { Elementer: Kunnskapsmål, } \\
\text { kompetansemål, grunnleggende } \\
\text { ferdigheter. Fagbegreper. Historikk. } \\
\text { Analysegrep. Begrepsoperasjonalisering. } \\
\text { Eksempler og illustrasjoner. } \\
2 \text { Aspekter: Kunnskapsbygging. Progresjon. } \\
\text { Elevers forkunnskaper. Vanskegrad. } \\
\text { Anvendelsesomrâder. Representasjoner og } \\
\text { motivasjon. Kunnskapskilder. Egen relasjon } \\
\text { til kunnskap. } \\
3 \text { Kunnskapsformer: Refleksjon. Analyse. } \\
\text { Kroppsliggjøring. } \\
4 \text { Refleksjon: Fagkunnskapens plass i økten. }\end{array}$} & \multirow{5}{*}{$\begin{array}{l}\text { III PROFESJONSKUNNSKAP } \\
\text { (FAGDIDAKTIKKOG PEDAGOGIKK) } \\
1 \text { Fagdidaktikk: IGP (individ - } \\
\text { gruppe - plenum), grunnleggende } \\
\text { ferdigheter, analyseskjema, speed } \\
\text { date. } \\
2 \text { Pedagogikk: Motivasjon, } \\
\text { Vygotsky, vurdering, proksimale } \\
\text { sone, scaffolding. } \\
3 \text { Ulike forhold til pedagogikk: } \\
\text { Andreas: Vygotsky som grunn- } \\
\text { innstilling, utviklingssonen, og } \\
\text { scaffolding i samsvar med } \\
\text { kunnskapssyn og eget mál for } \\
\text { lærergjerning. Savn av mer } \\
\text { kunnskap om motivasjon. } \\
\text { Birger: Pedagogisk teori som } \\
\text { akademisk og vanskelig å omsette } \\
\text { i praksis. Pedagogiske } \\
\text { hovedbegrep som noe rent } \\
\text { intuitivt, praksis som lærerikt } \\
\text { (metoder og «tanken bak dem»). } \\
\text { Birgitte: Pedagogikk viktig. } \\
\text { Vygotsky som møte mellom lærer } \\
\text { og elev. Utviklingssone svært } \\
\text { relevant, aktivt arbeid for å koble } \\
\text { pedagogikk til klasserommet. } \\
\text { Pedagogikk som bekreftelse, } \\
\text { organisering og samling av egne } \\
\text { tanker, pedagogisk psykologi som } \\
\text { noe som handler om livet. } \\
4 \text { Kunnskapskilder: } \\
\text { Campusundervisning, litteratur, } \\
\text { oppgaver. Oppvekst (Birgitte). } \\
5 \text { Veiledning: Noe fagdidaktikk, } \\
\text { lite pedagogikk. Forekomster av } \\
\text { pedagogiske begrep i skolens } \\
\text { plattform og møter, men avstand } \\
\text { mellom profesjonsspråk og } \\
\text { hverdagssprák. }\end{array}$} & SAMVIRKEASPEKTER \\
\hline & & $\begin{array}{l}\text { A KUNNSKAPSUTVIKLING I KLASSEROMMET } \\
1 \text { PEDAGOGISK GRUNNPERSPEKTIV: a) Vygotskys utviklingssone } \\
\text { (relasjonell og kunnskapsorientert). b) Fagdidaktikk og IGP. } \\
\text { Analyseskjema. } \\
2 \text { MOTIVASJON/TILPASNING: a) Motivasjonsgrad. b) Elevers } \\
\text { forutsetning og motivasjon. c) Tilpasning til elevnivâ, aktivering av } \\
\text { forkunnskap. } \\
3 \text { FORHANDLING, SAMSPILL, ANVENDELSE: a) Framforhandlet } \\
\text { kunnskap. b) Kunnskap som samspill. c) Fagkunnskap som anvendt } \\
\text { kunnskap. d) Kunnskapsfremmende arbeidsfaser, arbeidsformer og } \\
\text { arbeidsredskaper. e) Praksisnær fagdidaktikk som leverandør av }\end{array}$ \\
\hline \multirow{3}{*}{$\begin{array}{l}\text { II PRAKSISKUNNSKAP } \\
1 \text { Organisering: Motivasjon, plan, tidsbruk, } \\
\text { vurdering. } \\
2 \text { Arbeidsfaser: Oppstart, introduksjon, } \\
\text { instruksjon, elevarbeid, oppsummering, } \\
\text { avslutning. } \\
3 \text { Arbeidsformer: Lærerforedrag, } \\
\text { plenumsdialog, instrukser, analyse, par- } \\
\text { /gruppearbeid. } \\
4 \text { Arbeidsredskaper: Presentasjonsverktøy, } \\
\text { analyseredskap, oppgaver. } \\
5 \text { Elevfokus: Oppmerksomhet, spørsmál, } \\
\text { forutsetninger, forstảelse, tempo, } \\
\text { elevinnspill, nivâtilpasning, } \\
\text { tilbakemeldinger, notatbruk, aktivitetsnivâ, } \\
\text { elevkjennskap. } \\
6 \text { Rolle: Rollefortrolighet: instruktør, } \\
\text { veileder og kontrollør. Forhold til } \\
\text { kvalitetssikring, elevforutsetninger, } \\
\text { elevinnspill, kompleksitet, tydelighet, } \\
\text { metodevalg, erfaringsbredde. } \\
7 \text { Kunnskapskilder: Veileder, nettkilder, } \\
\text { fagdidaktikk. } \\
8 \text { Refleksjoner: Forholdet mellom fagstoff, } \\
\text { metodevalg og redskapsutforming. }\end{array}$} & & $\begin{array}{l}\text { RER: a) Tilgang på ressurser. Tidsrammer. } \\
\text { RSTÄELSE: a) Fagkunnskap som kognitiv versus } \\
\text { date). b) Klasseromsdialog: samspill elev- og } \\
\text { Fagkunnskapens transformasjon fra campus til } \\
\text { rholdet mellom kunnskapsfelt og helhet i økten. }\end{array}$ \\
\hline & & $\begin{array}{l}\text { GER OG ROLLEASPEKTER } \\
\text { teresse og motivasjon, innflytelse over } \\
\text { unnperspektiv (relasjon eller } \\
\text { e mellom læring og kontroll. } \\
\text { EELSE: a) Utviklingssonen og personlig } \\
\text { integrerende helhetsforstáelse. } \\
\text { : a) Samspill mellom lærer- og elev- } \\
\text { Elevers forutsetninger og motivasjon. } \\
\text { innskapen og motivasjon for } \\
\text { studier). }\end{array}$ \\
\hline & & $\begin{array}{l}\text { C RAMMEFAKTORER OG STUDIET } \\
1 \text { PRAKSISARENAEN OG STUDIET: a) Profesjonsspråket i praksis. b) } \\
\text { Kunnskap om motivasjon. c) Integrasjon av kunnskap, progresjon. } \\
\text { d) Delvis splittelse mellom akademisk kunnskap og praksis (Birger). e) } \\
\text { Applisering av pedagogikk på praksis (Birgitte og Andreas). } \\
2 \text { INNFLYTELSE: a) Studenters innflytelse på kunnskapstilfang. b) } \\
\text { Rammefaktorer: tid og kunnskapstilfang. } \\
3 \text { SOSIALE RELASJONER: a) Klasseromsatmosfære og relasjoner. }\end{array}$ \\
\hline
\end{tabular}

Figur 1. Kunnskapsområder og samvirkeaspekter (forstørret versjon i Vedlegg 1)

Den anvendte fagkunnskapen ble utviklet i interaksjon med elever innenfor rammer som lektorstudentene la til rette. Akademiske begreper ble operasjonalisert og kontekstualisert i møte mellom studenter og elever og de analyseobjektene de arbeidet med. 


\section{Praksiskunnskap}

Praksiskunnskapen framstod i liten grad som en tradisjon som praksisveilederne forvaltet og formidlet videre til studentene. Studentene fortalte om stor frihet til å velge undervisningsform og metoder, mens veilederne bidro med kritiske og konstruktive innspill. Studentene valgte praksisformer ut fra egen sosialisering, tidligere praksiserfaringer og innspill fra veileder.

Praksiskunnskap bestod av arbeidsformer, arbeidsfaser og redskaper (Figur 1, II). Det handlet om planleggingsaspekter som tidsrammer, framdrift og organisering og om arbeidsfaser fra oppstart og introduksjon via elevaktiviteter til oppsummeringer i plenum. Arbeidsformene dekket ulike typer formidling og organisering som ble fasilitert gjennom redskaper for presentasjon, gruppeaktivitet og plenumsaktivitet.

Praksiskunnskap berørte lektorstudenters og elevers forutsetninger. Lektorstudentene la vekt på å skape dialog med elever, inkludere elever i læringsarbeidet og følge opp elevenes bidrag. Lektorstudentene framhevet egen rolle og rolleutøvelse som viktig, for eksempel å beherske balansen mellom åpenhet og kontroll. Både organiserings- og arbeidsformer og personlige aspekter var altså viktige. Vekt ble også lagt på prosess, framdrift, retning og mål og hvordan arbeidsformer kunne bidra til læring.

\section{Profesjonskunnskap}

Profesjonskunnskap var representert gjennom temaer og begreper fra undervisning og studielitteratur i pedagogikk og fagdidaktikk (Figur 1, III). Studentene viste til pedagogiske begreper som «motivasjon» og «vurdering» og begreper fra Vygotsky som «den proksimale utviklingssonen» og «stillasbygging». Fra didaktikken ble nevnt undervisningsformer som «IGP» (individuelt, i gruppe, i plenum) og "speed date», og det ble brukt et skjema for personkarakterisering hentet fra en fagdidaktikkbok (Figur 2). Intervjuene viste at studentene hadde ulike forhold til pedagogikk, noe som influerte på deres forhold til kunnskapsintegrasjon. Dette blir beskrevet senere i artikkelen.

\section{Kunnskapssamvirke}

Det finnes elementer i hvert av kunnskapsområdene som peker mot samvirke med andre kunnskapsområder. For eksempel vil anvendelse av fagkunnskap involvere aktivitets- og arbeidsformer fra praksiskunnskapen, mens arbeidsformer og elevfokus influerer på forståelse og tilrettelegging av fagbegreper. Personlig erfaring og forhold til kunnskap og rolle befinner seg i grensefeltet mellom fagkunnskap og praksiskunnskap.

I analysen fant vi også mer direkte samvirkekonstellasjoner mellom kunnskapsområder (Figur 1, A-C). Vi har samlet disse samvirkeaspektene i tre 
hovedområder: kunnskapsutvikling i klasserommet (A), personlige forutsetninger (B) og rammefaktorer knyttet til praksisskolen og lektorprogrammet (C).

Hovedfokus i artikkelen er de to første områdene, som blir vektlagt i det følgende, mens det sistnevnte blir omtalt i mindre grad. Kunnskapsutvikling i klasserommet (A) blir illustrert gjennom tre eksempler fra undervisning og veiledning, mens personlige forutsetninger (B) blir framstilt med basis i intervjumaterialet.

\section{Kunnskapssamvirke i klasserom og veiledning: tre eksempler}

De følgende eksemplene viser lektorstudentene i sentrale faser av undervisningen i de to klassene: introduksjon, gruppearbeid og plenumsoppsummering. Eksemplene demonstrerer at studentene står i en kombinert undervisnings- og læringssituasjonen; de er selv «lærlinger» under veiledning, samtidig som de er lærere for elevene. I eksempel 1 og 3 ligger hovedvekten på studentenes undervisningsarbeid i klasserommet, mens eksempel 2 tar utgangspunkt i veiledningssituasjonen.

\section{Eksempel 1}

Eksempel 1 er et utsnitt fra den første av to undervisningsøkter på skole B, ledet av lektorstudent Birgitte. Etter en innledende oppfriskning av kunnskap om personkarakterisering hadde Birgitte gitt en intro til filmen The Perks of Being a Wallflower (Chbosky, 2012) i dialog med elever som kjente filmen fra før. Birgitte introduserte nå et analyse- og notatskjema (Figur 2) som var hentet fra studentenes studielitteratur (Simensen, 2007) etter forslag fra veileder Brian, og som elevene skulle bruke når de så filmen.

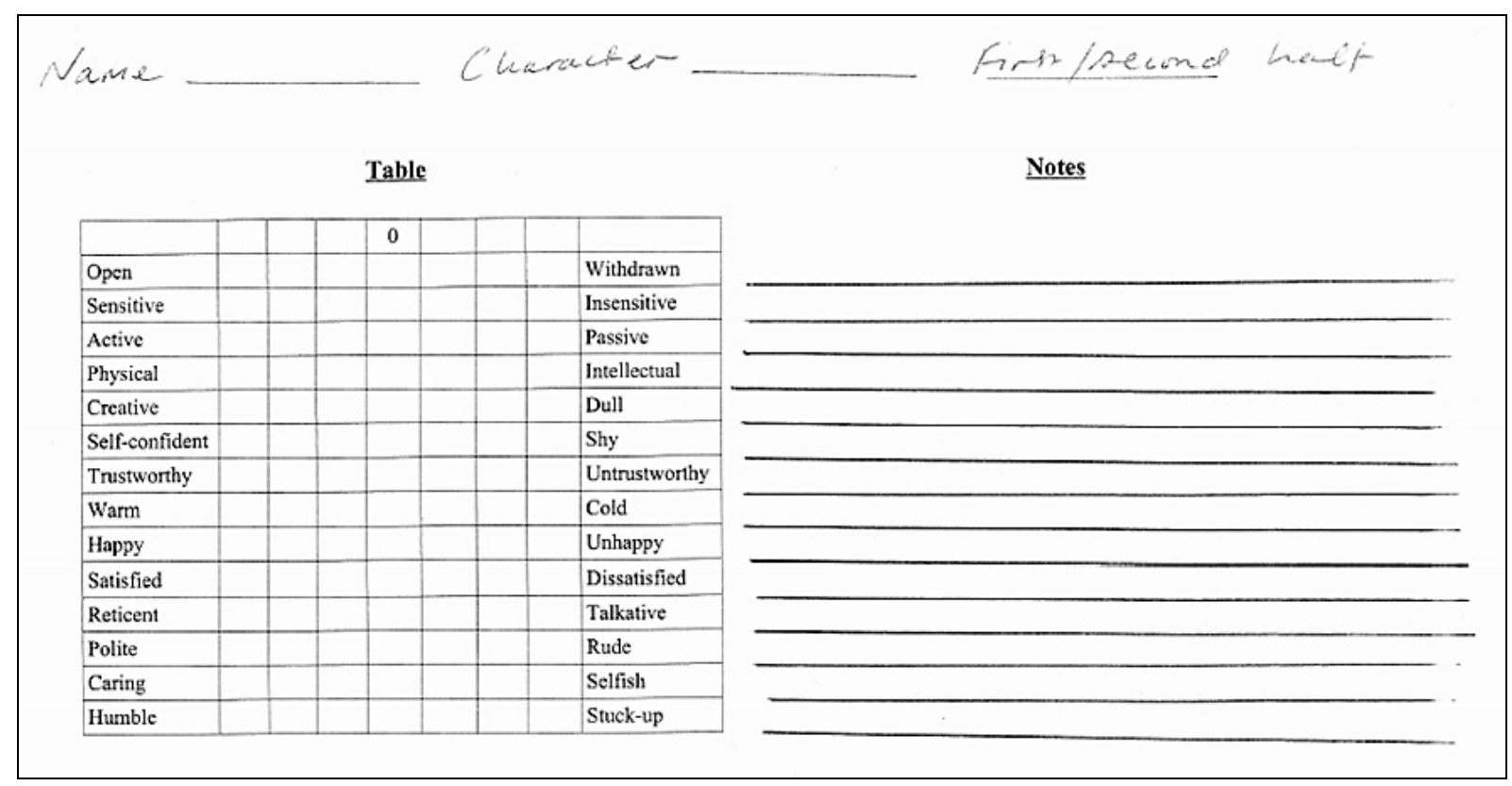

Figur 2. Analyse- og notatskjema fra skole B 
Studentene hadde lagt til ekstra notatplass på skjemaet og bestemt at elevene skulle gjøre notater om hver sin tildelte person fra filmen. Birgitte instruerte elevene om hvordan de skulle krysse av på skjemaet. Hun viste hvordan hovedpersonen Charlie kunne plasseres i spennet mellom ordene «open» og «withdrawn». Da en elev spurte om betydningen av et av ordene, startet Birgitte en gjennomgang av alle begrepene i dialog med klassen. Birgitte gikk gjennom flere ordpar før hun ba elevene selv si fra om ord de var usikre på. Det kom spørsmål om ordparene «Humble - Stuck up» og «Physical - Intellectual». Birgitte forklarte disse ved hjelp av innspill fra klassen, og kommenterte at ett av ordene hadde hun og medstudenten måttet slå opp selv.

På spørsmål om hva ordet «intellectual» betydde, nølte Birgitte. «You are asking hard questions», sa hun og vendte seg mot veileder med en litt oppgitt latter. Hun tenkte høyt foran klassen og forsøkte seg med ordet «smart», forkastet det, og lot elevene spille inn en serie med forslag. Birgitte vurderte innspillene, men var ikke tilfreds og prøvde å illustrere ordparet «physical intellectual» ved å beskrive forskjellen mellom seg og søsteren: «... and I really, I'm sort of an academic, or I like sitting down reading books and, and I like, ehm, and she's more of an active, more like physical». Så innså hun at hun gikk i ring, utbrøt «hah» og lo en hjertelig latter sammen med hele klassen før hun slo ut med armen i retning veileder og sa: «Now you can take over». Veileder gav henne kreditt for forklaringen og kom med en tilleggsforklaring før Birgitte tok føringen igjen og spurte om dette gav mening. Elevene bekreftet det, og Birgitte sa med en liten latter: «Good», «I’m glad, Okey», før hun spurte om det var flere ord som trengte forklaring.

Denne sekvensen viste hvordan Birgitte og hennes medstudent hadde lagt opp til å operasjonalisere fagtemaet "personkarakteristikk» for elevene ved å hente støtte i analyseskjemaet fra fagdidaktikkboka. Skjemaet og fagbegrepene ble introdusert gjennom en plenumssamtale som studenten midtveis snudde fra en lærerstyrt samtale til en dialog basert på elevers spørsmål og innspill. Denne praksisfaglige samtaleformen tydeliggjorde elevenes forkunnskaper og læreforutsetninger og utfordret lektorstudenten på hennes egen begrepskunnskap.

Den felles begrepsutforskningen i dialogen ble mot slutten nesten eksplorerende, og dette ble fasilitert gjennom måten studenten utøvde sin lærerrolle på. Da hun nevnte at hun hadde måttet slå opp et ord selv, signaliserte hun at også hun var i en læringsprosess. Etter hvert inntok hun en enda mer åpen posisjon da hun slet med å forklare ordet «intellectual» og brukte seg selv og sin søster som eksempel. Da det ikke lyktes, tydde hun til latter og humor for å ufarliggjøre situasjonen, i stedet for å bli forlegen eller gå i forsvar.

I etterveiledningen var Birgitte selvkritisk til flere trekk ved økten, blant annet egen begrepsforklaring, men hun framhevet at det var en god klasseromsatmosfære:

I am satisfied with the students being able to show signs of weakness, in the students' laughing, instead of, instead of, I mean laughing in a good way that we can have 
humor about it. Ehm, instead of it all being quiet or, it's like a nice atmosphere in here.

I feel like I can relate to the pupils.

Birgitte la altså vekt på relasjoner og åpenhet i undervisningsrommet. Med dette antydet hun en relasjonell grunnholdning som senere ble bekreftet i intervjuet med veileder Brian som sa at Birgitte var svært åpen i klasserommet og uredd for å vise vennlighet eller bli såret. Dette relasjonelle aspektet ble videre utdypet i intervjuet med Birgitte, og vi kommer tilbake til dette senere i delen om personlige forutsetninger.

\section{Eksempel 2}

I starten av den andre økten i klasse $\mathrm{B}$ så elevene ferdig filmen The Perks of being a Wallflower. Deretter fulgte gruppearbeid og flere runder med «speed date», ledet av student Birger, hvor elevene representerte sin filmperson i vekslende møter med medelever som representerte andre filmpersoner. Arbeidet var preget av høy muntlig aktivitet, men siden det ikke ble gjort lydopptak av gruppeaktiviteten, bygger eksempel 2 på samtalene i før- og etterveiledning.

I veiledningen var studenter og veileder opptatt av hvordan gruppeaktiviteten skulle organiseres og hvilke læringsformål den kunne fremme. Studentene la vekt på at elevene skulle bruke muntlig engelsk, og at de skulle formidle og utvikle sin forståelse av filmkarakterene med støtte i notater fra filmen. Birger viste til sin semesteroppgave om erfaring med «speed date» fra forrige praksisperiode og pekte på at arbeidsformen kunne stimulere muntlig språkbruk: «they talk so much [...] because they are allowed to play a role, they're not themselves when they're speaking». Alle var enige om at dette målet ble nådd, at det ble lav terskel for å delta. De la dermed vekt på aktivitetsnivået mer enn på det språklige nivået.

Den andre delen av formålet med «speed date» var å utvikle forståelsen av filmkarakterene. Her hadde studenter og veileder noe ulike oppfatninger. Veileder etterlyste mer aktiv bruk av analyseskjemaet i gruppearbeidet og utfordret studentenes forståelse av «speed date» som rollespill. Studentene forstod «speed date» som en øvelse hvor elevene delte informasjon om sin filmkarakter, mens veileder spurte om «speed date» snarere var et rollespill hvor elever gikk inn i og spilte ut sin filmkarakter og på den måten ble kjent med karakteren på en mer intuitiv måte.

Veileder viste til kopier fra en fagdidaktikkbok (Simensen, 2007) som han hadde gitt studentene og hvor det var foreslått at elever kunne spille journalister som intervjuet filmkarakterer. Veileder antydet at et slikt rollespill for eksempel kunne ta utgangspunkt i en dramatisk scene i filmen hvor hovedkarakteren var involvert i en slåsskamp i skolegården. Studentene hadde ikke plukket opp denne ideen, og hadde i stedet latt elevene bruke spørsmål som ifølge veileder dels la opp til rollespill og dels brøt med rollespillet.

I etterveiledningen ble det en diskusjon mellom Birger og veilederen. Veileder Brian fastholdt at rollespill kunne få underbevisste aspekter ved karakteren 
til å tre fram for elevene så de kunne få en annen type forståelse av personen og av indirekte karakterisering i film. Dette kunne elevene så bearbeide analytisk ved å sammenligne og respondere på hverandres erfaringer. Birger, og også Birgitte, medgav at det kunne ha vært mulig å styrke elementet av rollespill i «speed date»-øvelsen, men Birger holdt det for urealistisk at elevene skulle gjøre nye erkjennelser om sin filmkarakter i løpet av en slik «speed date». Veileder vedgikk da at Birger kunne ha rett i dette.

Birger syntes altså å gi uttrykk for en noe annen læringsforståelse enn sin veileder. Birger var opptatt av kunnskapsutvikling som informasjonsutveksling, mens veileder framhevet en mer kroppslig og intuitiv form for kunnskapsutvikling. De viste dermed hvordan en praksisform kunne åpne for ulike forståelser av kunnskap og læring. Ulike utforminger av «speed date» ville kunne stimulere ulike typer læringsprosesser, kognitive eller mer intuitivt-kroppslige. Birgers bruk av «speed date» viste også et annet aspekt ved kunnskapsintegrasjon, nemlig hvordan en arbeidsform ble overført fra én praksiskontekst til en annen via en semesteroppgave i profesjonsfaget.

\section{Eksempel 3}

I undervisningsøkten på skole A ledet lektorstudent Andreas en avsluttende plenumsoppsummering. Før dette hadde han først introdusert retoriske begreper og deretter latt elevene analysere et leserinnlegg, individuelt og i grupper. Økten bygget på en IGP-struktur (individuelt, i gruppe, i plenum) hentet fra fagdidaktikk. Oppsummeringen var i hovedsak lærerstyrt, men elever bidro også med mer selvstendige innspill.

Plenumsoppsummeringen foregikk som en samtale på flere begrepsnivå. Ett nivå var klassiske retorikkbegreper som «forstandig(het)», «dyd», «velvilje» og «autentisitet». Et annet nivå var forklarende begreper som studenten hadde gitt $\mathrm{i}$ introduksjonen, slik som «troverdighet» (for «etos») og «god moral» (for «dyd»). Et tredje nivå var begreper som ble tatt i bruk underveis, slik som: «kunnskap» som ble knyttet til «dyd» og «forstand». Med ett unntak var det bare lektorstudenten selv som aktivt anvendte de klassiske retoriske begrepene (nivå 1) i samtalen, mens han og elevene delte på bruken av de utfyllende begrepene på nivå 2. Tilleggsbegrepene på tredje nivå framstod som ord elevene tok i bruk for å fortolke meningen i fagbegrepene. I tillegg til begrepsnivåene influerte også elevenes kontekst på oppsummeringssamtalen, ettersom flere elever kjente til tekstforfatteren og oppvekstmiljøet som var omtalt i teksten.

Nivåene demonstrerte et samspill mellom fagbegreper og dagligbegreper som var noe nølende, enten fordi elevene ikke var fortrolige med klassiske retoriske begreper, eller fordi det ikke var gjort klart at de skulle bruke begrepene aktivt. På denne måten ble studentens intensjon med økten ikke helt innfridd. Samtalen tydet likevel på at elever var i prosess med å forstå fagkunnskapen, selv om de ikke brukte de mest utpregede fagbegrepene. 
Bare én av elevene tok i bruk et av de klassiske begrepene ved å stille spørsmål ved tekstforfatterens autentisitet. Han ville ikke frakjenne tekstforfatteren all autentisitet, men ville nyansere bildet. Bidraget fra eleven fikk positiv respons fra lektorstudent Andreas, men elevens nyansering fikk likevel ikke plass i den endelige oppsummeringen av tekstens etos til slutt i undervisningsøkten.

Plenumssekvensen viste hvordan en anvendt kunnskap ble til gjennom kryssende samspill: mellom retorikkfaglige begreper og dagligbegreper, mellom fagkunnskap og dialog som arbeidsform og mellom lektorstudenten og elevene. Kunnskapsbyggingen var preget av forhandlinger, av klasseromskontekst og elevbakgrunn og av de mulighetene og begrensningene som fantes i samspillet mellom fagkunnskap og arbeidsform. I samtale med veileder Anette sa Andreas at han opplevde det som krevende å holde tak i helheten i den kunnskapen som ble utviklet gjennom dialogen med elever. Han nevnte dette som et av sine «utviklingspunkt»: «når jeg tar den der oppsummeringen i plenum, [...] potensielt sett så kan det komme mange gode innspill, men hvordan evner jeg å sammenfatte det?» Veileder mente at dette først og fremst var et spørsmål om erfaring og modning.

\section{Refleksjoner over de tre eksemplene}

De tre eksemplene viser noen sentrale momenter ved det kunnskapssamvirket som fant sted i undervisningsøktene og veiledningssamtalene. Vi vil særlig peke på de momentene som handler om forhandling, samspill og anvendelse (Figur1, A3), og det som handler om kunnskapsforståelse (Figur 1, A5).

Et sentralt trekk i eksempel 1 og 3 er at kunnskap framforhandles. Kunnskapen ble operasjonalisert og tilpasset gjennom et samspill mellom lærere og elever og deres forutsetninger. Eksemplene viser hvordan lærerens kunnskapsforståelse ble utfordret av elevenes, og hvordan elever prøvde å strekke sin forståelse for å knytte an til begreper de ble presentert for. Prosessen med å utvikle en felles kunnskap ble gjennomført i noe ulik grad i de to eksemplene. I eksempel 1 kom studenten elevene langt i møte, mens det i eksempel 3 fortsatt gjenstod et arbeid før det øverste nivå av fagbegreper utgjorde en felles kunnskap. I eksempel 2 foregikk en forhandling og brytning mellom ulike forståelser av forholdet mellom fagkunnskap og praksisform.

I eksemplene har dialogen en sentral plass som medium for samspillet og brytningene mellom elevers og læreres forståelse. Eksemplene demonstrerer hvordan muligheter og begrensinger i dialogen influerte på kunnskapsdanningen. Andreas pekte også på hvordan dialogen som praksisform var avhengig av lektorstudentens personlige utvikling og erfaring.

I begge undervisningsøktene stod anvendelse av kunnskap sentralt. Studentene valgte tekst- og filmeksempler som skulle gi fagbegrepene en konkret anvendelse, og de valgte arbeidsformer og organisering som kunne støtte dette. 
Eksemplene viser samtidig at samspillet mellom kunnskapsutvikling og arbeidsformer ikke var optimalisert, og at det var potensial for videre utvikling.

Kunnskapsforståelse ble et sentralt aspekt ved kunnskapssamvirket i eksempel 2. Birgers forståelse av «speed date» som medium for informasjonsutveksling ble utfordret av veileder som åpnet for en mer fysisk, erfaringspreget læring. Birger og veileder aksentuerte fagbegrepet personkarakteristikk på ulike måter og knyttet dette til ulike forståelser og utforminger av praksisformen «speed date». I eksempel 3 hadde Andreas intensjoner om en felles kunnskapsutvikling i klasserommet, men han opplevde manglende fortrolighet med praksisformen som et hinder for å realisere intensjonene. Veileder forstod dette som spørsmål om modning, uten å gå inn på hvordan man mer konkret kunne utvikle støttestrukturer for en slik kunnskapsutvikling.

I intervjuene kommenterte studentene forholdet mellom kunnskapsområder i den undervisningsøkten de hadde gjennomført. De framhevet at det var et tydelig fagfokus i økten, hvor valget av praksisfaglige arbeidsformer var underordnet det faglige anliggendet, bortsett fra i små episoder hvor klasseledelse kom i forgrunnen. Dette ble ikke framstilt som en rangering av kunnskapsområdene, men framstod som en konstatering av fagkunnskapens betydning $\mathrm{i}$ undervisning på videregående skole.

\section{Personlige forutsetninger og forankring av kunnskapssamvirke}

I eksemplene har vi sett hvordan samvirke mellom fagkunnskap og praksisformer fant sted i undervisningen og i veiledningen, men disse delene av datamaterialet sier lite om de mer overordnede forståelsesrammene for et slikt samvirke. Først i intervjuene ble det klart at studentene hadde til dels ulikt forhold til profesjonskunnskap og at dette bidro til ulike aksentueringer av yrkesforståelse og til dels også influerte på kunnskapssyn og selvoppfatning. Når det gjaldt den fagdidaktiske delen av profesjonskunnskapen, var studentene enige om at dette var et kunnskapsfelt som i stor grad kommuniserte godt med praksisutøvelsen. Det var i utsagn om pedagogikk at studentene skilte lag.

Birger var kritisk i sin beskrivelse av pedagogikk. Han omtalte det som en «hamring» om temaer som «Vygotsky og sånne ting». Selv om han ikke avviste «hovedtankene» i pedagogikken, mente han disse var ganske intuitivt tilgjengelige. Det var praksis som var Birgers foretrukne læringsarena, det var i klasserommet at ting ble tydeliggjort, mens han opplevde pedagogikk som en akademisk kunnskap. For Birger var lærerens profesjonelle yrkeskunnskap knyttet til fagkunnskap og til en praksiskunnskap forstått som håndverk på linje med yrker som tannlege eller snekker.

Selv om Birger var kritisk til pedagogikkfaget, ville han ikke etterlate seg inntrykk av at han så på pedagogikk som «noe tull». Han pekte på at han kunne ha «misforstått pedagogikken», at dette var gått litt over hodet på ham, og at 
pedagogisk-psykologisk kunnskap kunne ha betydning i arbeidssituasjoner hvor man arbeidet med tett oppfølging av enkeltelever. Det var slik sett en viss spenning i Birgers forhold til pedagogisk kunnskap.

Birgitte fortalte om et nært forhold til pedagogikk, formidlet gjennom en far som hadde snakket pedagogikk med henne fra hun var liten. For Birgitte var Vygotskys utviklingssone et sentralt tema med stor relevans for praksis:

Kanskje ikke [det] er kjempeviktig å vite at det kom fra Vygotsky, men begrepet om utviklingssoner, at det er veldig relevant [...] selv om jeg også ser hvor praksisfjernt det kan oppleves. Men, tenker jeg, da må jo vi jobbe med å koble det og se hvor aktuelt det er i klasserommet.

Pedagogikk var for Birgitte noe som bekreftet «tanker jeg vet jeg på en måte har», som gav en forståelse som var «mer organisert og samlet» av «hvordan det henger sammen». Pedagogisk psykologi beskrev hun som kunnskap som «går så veldig på det ekte livet», og som kunne hjelpe henne «å bli klar over hvorfor ting er som de er».

Som før nevnt la Birgitte vekt på relasjoner i klasserommet. Dette aspektet dukket også opp flere ganger i intervjuet:

Jeg tenker relasjonelt, [...] det går jo litt på pedagogikk [...] hvordan alle trenger å føle seg sett og at noen er interessert i dem, [...] hvis jeg klarer å vise dem det, så vil det hjelpe dem, eller så vil de være mye mer interessert i å høre på meg, og da vet jeg at jeg lettere kan formidle fagkunnskap. Så sånn relasjonell kunnskap, [...] tenker jeg som kjempeaktuelt.

For Birgitte var det altså en tett sammenheng mellom relasjoner og kunnskaps. I omtalen av en pedagogikkforelesning på campus knyttet hun det relasjonelle til Vygotsky: «når han [foreleseren] fortalte om hvordan han møtte den eleven der, så var jo det Vygotsky». Birgittes forhold til pedagogikk var likevel ikke tydelig uttalt i veiledningskonteksten. Veilederen var ikke klar over hennes positive forhold til pedagogikk, og trodde hun var like kritisk som medstudent Birger.

Andreas var den eneste av studentene som viste til pedagogiske perspektiver i veiledningen, og i intervjuet utdypet han hvordan hans tenkning var knyttet til profesjonsfaglige perspektiver, både IGP-strukturen fra fagdidaktikk og Vygotskys begrep om den proksimale utviklingssonen. Andreas vektla utviklingssonen som et møte mellom ytre kunnskap og indre utvikling, som elevers møter med kompetente andre, og det å bygge støttestrukturer for slike møter. Andreas beskrev utviklingssonen som et uttrykk for hans eget kunnskapssyn og yrkesforståelse:

Det er for meg, noe av det mest anvendelige er akkurat det perspektivet der. Det er [den] proksimale utviklingssone og scaffolding, stillasbygging, som har truffet meg mest da, og som jeg kjenner at det her, det her er faktisk noe som stemmer overens med min kjennskap til verden, mitt kunnskapssyn og mitt ønske med min lærergjerning egentlig. 
Andreas var den som tydeligst brukte et profesjonsfaglig vokabular i veiledning og intervju, samtidig som han opplevde det vanskelig å bruke et slikt profesjonsspråk i møte med erfarne lærere på lærerrommet. Andreas’ ideal var en helhetlig sammenheng mellom kunnskapsområdene i undervisningen, samtidig som han opplevde det krevende å realisere denne helheten gjennom å transformere fagkunnskap inn i praksiskonteksten.

Beskrivelsene $\mathrm{i}$ det foregående viser at studentene forankret sin yrkesforståelse på ulike måter. Andreas og Birgitte uttrykte en tydelig forankring i profesjonsfaget, mens Birger i større grad søkte en forankring i en praksisfaglig tilnærming. Hos Andreas og Birgitte møtte vi noe ulike aksentueringer av et Vygotsky-inspirert perspektiv, en relasjonell aksentuering av utviklingssonen hos Birgitte og en mer kunnskapsfokusert aksentuering hos Andreas. Selv om også Andreas og Birgitte så utfordringer i forholdet mellom pedagogikk og praksis, så de det som en positiv oppgave å realisere et samvirke, og de arbeidet aktivt for dette.

Birgers forhold til pedagogikk var som nevnt ikke helt entydig. Han beskrev pedagogikk som et akademisk fag med liten relevans for praksis, samtidig som han ikke ville framstå som for pedagogikk-kritisk. Dette kan muligens indikere at Birger opplevde et ubehag ved å utfordre noe han oppfattet som en hegemonisk diskurs innenfor lærerutdanningen, en opplevelse av at en pedagogikkfundert yrkesforståelse har sterkere legitimitet i lektorutdanningen enn en yrkesforståelse som er fundert i en praksisfaglig håndverks-tilnærming.

\section{Kunnskapsintegrasjon som mulighet og utfordring}

I denne studien har vi forsøkt å belyse aspekter ved kunnskapsintegrasjon i lektorstudenters undervisningspraksis i fagene norsk og engelsk. Vår studie bekrefter delvis bildet fra tidligere studier av en praksisveiledning som inneholder lite eksplisitt profesjonsfaglig kunnskap eller refleksjon (Fosse, 2011, 2016; Fosse \& Hovdenak, 2014; Jahreie \& Ottesen, 2010; Ottesen, 2006). Studien viser imidlertid også, i likhet med enkelte tidligere studier (Haugan, 2014), at utdypende intervjuer kan synliggjøre at studenter har en sterkere profesjonsfaglig refleksjon og forankring enn det som kommer fram i veiledningssamtaler.

Sammenlignet med undersøkelser av studenters eksamensbesvarelser på campus (Vestøl, 2014) viser vår studie at kunnskapsintegrasjon i praksissituasjonen preges mer av anvendt kunnskap, av interaksjon mellom aktører og av interaksjon mellom fagkunnskap og elevers førkunnskaper. Mens eksamensbesvarelser kan ha tydelige innslag av profesjonskunnskap, er slik kunnskap lite eksplisitt i undervisnings- og veiledningssituasjonen, men kan som nevnt bli artikulert $\mathrm{i}$ andre situasjoner.

Materialet gjenspeiler en varierende grad av koherens i lektorutdanningen på både begrepsnivå og strukturnivå (Grossmann et al., 2008; Hammerness, 2006, 
2013). To av studentene har et personliggjort pedagogisk grunnperspektiv som signaliserer at de forholder seg til grunnleggende begreper (begrepskoherens) som også er personliggjort (biografisk koherens) og som potensielt også vil kunne prege deres videre yrkesliv (overgangskoherens) (Heggen \& Smeby, 2012).

I lys av Bernsteins (1975) integrasjonsbegrep beskriver studentene i vår studie forholdet mellom fagkunnskap, praksiskunnskap og fagdidaktikk på en måte som har trekk av en integrasjonskode, mens de i forhold til pedagogikk er splittet mellom kolleksjonskode og integrasjonskode. Studentene synes å forholde seg ulikt til overgripende ideer eller orienteringspunkt for integrasjon. Mens Vygotsky-inspirerte pedagogiske grunnperspektiv utgjør slike orienteringspunkt hos to av studentene, søker den tredje studenten en forankring i en forståelse av undervisning som håndverk. Vi har også sett hvordan det Vygotsky-inspirerte orienteringspunktet hos to av studentene får ulik aksentuering. Studentenes ulike valg av forankring reiser viktige spørsmål om bakgrunn og drivkrefter for slike valg og spørsmål om hvordan lektorutdanningen forholder seg til ulike valg av forankring.

De perspektivene studentene forankrer sin forståelse i, kan oppfattes som artefakter på Wartofskys andre nivå, det vil si som bekreftende og konsoliderende fortolkingsrammer for organisering av kunnskapselementer (Cole, 1996; Daniels, 2001; Wartofsky, 1973/1979). Tydeligst er dette hos den studenten som søker forankring i læreryrket som en stabil håndverkstradisjon. Hos de to Vygotsky-orienterte studentene har forankringen en tyngde utover selve praksistradisjonen. En slik forankring kan romme kimer til en selvstendighet som potensielt kan utfordre konvensjoner og dermed nærme seg en tredje-nivåartefakt.

Det må likevel presiseres at tredje-nivå-artefakter primært ikke viser til det som skjer på et individuelt handlingsnivå, men til prosesser på et kollektivt virksomhetsnivå. I materialet fra vår studie er studentenes forankringspunkt ikke tydelig relatert til den kollektive virksomheten på campus og i praksisskolen utover klasseromsaktiviteten. Materialet beskriver primært andrenivået i studentenes kunnskapsdanning og kunnskapsintegrasjon som et individuelt fenomen, og forholdet til tredjenivået som institusjonelt og kollektivt fenomen er lite tydelig.

Det kan være et viktig anliggende for lærerutdanningen å tydeliggjøre hvordan studenters kunnskapsintegrasjon og kunnskapsforankring forholder seg til et institusjonelt og kollektivt tredjenivå. Lektorstudenter er i betydelig grad avhengige av å gjøre seg kjent med konvensjoner på andrenivået, særlig for å kunne navigere i komplekse samspill i praksisfeltet. Det vil trolig kreves grep av utdanningen hvis studenter skal kunne introduseres for tredjenivå-perspektiver på en måte som gjør dem i stand til å utvikle og reflektere over egen posisjon. I vårt materiale ser vi kanskje en kime til en slik refleksjon når student Andreas beskriver sin vegring mot å bruke sitt personlig tilegnede pedagogikkfaglige språk i møte med lærerpersonalet på praksisskolen. 
Vår studie tegner et tentativt riss av noen aspekter ved kunnskapsintegrasjon slik den framtrer i lektorstudenters praksis. Studien peker på hvordan de enkelte kunnskapsfeltene har elementer som peker utover seg selv i retning av andre kunnskapsfelt; den peker på den rolle anvendt kunnskap spiller i integrasjonen og hvordan integrasjon skjer i samspill mellom kunnskap og arbeidsformer, i samspill mellom aktører og i samspill mellom kunnskapsnivåer. Studien peker også på betydningen av å forankre kunnskapsintegrasjon i overgripende perspektiver og gir innspill til en teoretisk refleksjon over dette. Dersom man legger til grunn at metarefleksjon er en betingelse for kunnskapsintegrasjon (Schneider, 2012), vil det være en oppgave for lærerutdanningen å utvikle en kvalifisert forståelse av kunnskapsintegrasjon som fenomen og også å utvikle den analytiske og operative kompetansen som er nødvendig for at studenter og ansatte kan bevisstgjøre sitt eget forhold til samspill mellom kunnskapsfelt i studier og profesjonsfelt.

\section{Takk}

Denne studien er utført med støtte fra ProTed - Senter for fremragende lærerutdanning.

\section{Om forfatterne}

Jon Magne Vestøl er professor ved Universitetet i Oslo. Hans forskningsinteresser omfatter blant annet designperspektiver på undervisning og læring. Institusjonstilknytning: Institutt for lærerutdanning og skoleforskning, Universitetet i Oslo, Postboks 1099 Blindern, 0317 Oslo.

E-post: j.m.vestol@ils.uio.no

Anne Kristin Dahl er universitetslektor ved Universitetet i Oslo. Hennes interessefelt er nyutdannede læreres første år i lærerprofesjonen. Hun arbeider nå med en longitudinell studie av de særlige utfordringene de nyutdannede møter og hvordan de takler disse.

Institusjonstilknytning: Institutt for lærerutdanning og skoleforskning, Universitetet i Oslo, Postboks 1099 Blindern, 0317 Oslo.

E-post: annekda@ils.uio.no

Tove Seiness Hunskaar er universitetslektor ved Universitetet i Oslo. Hennes interessefelt er partnerskap mellom skole og universitet i samarbeid om lærerutdanning.

Institusjonstilknytning: Institutt for lærerutdanning og skoleforskning, Universitetet i Oslo, Postboks 1099 Blindern, 0317 Oslo.

E-post: t.s.hunskaar@ils.uio.no 


\section{Referanser}

Bakken, J. (2009). Retorikk i skolen. Oslo: Universitetsforlaget.

Bernstein, B. (1975). Class, Codes and Control. Volume 3. Towards a Theory of Educational Transmissions. London: Routledge.

Bjerkholt, E. (2013). Apning av lukkede rom. En kvalitativ studie av innholdet og dialogene i veiledningssamtaler mellom nyutdannede lcerere og lokale veiledere. $\mathrm{PhD}$-avhandling, Universitetet i Oslo.

Bråten, I. \& Thurman-Moe, A. C. (1998). Den nærmeste utviklingssonen som utgangspunkt for pedagogisk praksis. I I. Bråten (red.), Vygotsky i pedagogikken (s. 123-143). Oslo: Cappelen Akademisk Forlag.

Buchmann, M. \& Floden, R. E. (1992). Coherence, the Rebel Angel. Educational Researcher, 21(9), 4-9. doi: http://journals.sagepub.com/doi/10.3102/0013189X021009004

Chbosky, S. (regi) (2012). The Perks of Being a Wallflower. L. Halfon, R. Smith \& J. Malkovich (produksjon). USA: Summit Entertainment.

Cochran-Smith, M. \& Lytle, S. L. (1999). Relationship of Knowledge and Practice: Teacher Learning in Communities. I A. Iran-Nejad \& P. D. Pearson (red.), Review of Research in Education, 24 (s. 249-306). Washington DC: American Educational Research Association.

Cole, M. (1996). Cultural Psychology. A Once and Future Discipline. Cambridge MA: Harvard University Press.

Daniels, H. (2001). Vygotsky and Pedagogy. London: RoutledgeFalmer.

Engeström, Y. (1987). Learning by Expanding. An Activity-Theoretical Approach to Development Research. Helsinki: Orienta Konsultit Oy.

Eraut, M. (2004). Informal learning in the workplace. Studies in Continuing Education, 26(2), 247-273. doi: https://doi.org/10.1080/158037042000225245

Fenstermacher, G. D. (1994). The Knower and the Known: The Nature of Knowledge in Research on Teaching. Review of Research in Education, 20(3), 3-56. doi: http://journals.sagepub.com/doi/pdf/10.3102/0091732X020001003

Fosse, B. O. (2011). Lcererstudenters innramming og forståelse av tilpasset opplæring. En studie av kollektive leringsprosesser i ulike kontekster ved en praktisk-pedagogisk utdanning. PhD-avhandling, Universitetet i Oslo.

Fosse, B. O. (2016). Transformering av kunnskap mellom campus og skole i lærerutdanningen. Acta Didactica Norge, 10(2), 235-251. doi: http://dx.doi.org/10.5617/adno.2498

Fosse, B. O. \& Hovdenak, S. S. (2014). Lærerutdanning og lærerprofesjonalitet i spenningsfeltet mellom ulike kunnskapsformer. Norsk Pedagogisk Tidsskrift, 98(2), 66-79. doi: https://doi.org/10.18261/issn.1893-8981-2017-02-06

Granlund, L. (2013). Hvordan oppdras oppdragerne? En sammenlignende studie av en lcrerutdanning for steinerskolene og en offentlig lærerutdanning. $\mathrm{PhD}$-avhandling, Universitetet i Bergen.

Grossmann, P., Hammerness, K., McDonald, M. \& Ronfeldt, M. (2008). Constructing Coherence. Structural Predictors of Perception of Coherence in NYC Teacher Education Programs. Journal of Teacher Education, 59(4), 273-287. doi: http://journals.sagepub.com/doi/10.1177/0022487108322127

Hammerness, K. (2006). From Coherence in Theory to Coherence in Practice. Teacher College Record, 108(7), 1241-1265. doi:

https://ed.stanford.edu/sites/default/files/from_coherence_in_theory_to_coherence_in_pra ctice.pdf 
Hammerness, K. (2013). Examining Features of Teacher Education in Norway. Scandinavian Journal of Educational Research, 57(4), 400-419. doi: https://doi.org/10.1080/00313831.2012.656285

Haugan, J. A. (2011). A systematic review of research regarding Norwegian general teacher education 2000-2010. Nordic Studies in Education, 31(4), 229-244. doi: https://www.idunn.no/np/2011/04/art03?languageId=1

Haugan, J. A. (2014). Lererstudenters praktiske handlekraft. En kvalitativ studie av fire allmennlcererstudenters verbaliserte refleksjoner i løpet av praksisopplceringen fra et aktivitetsteoretisk perspektiv. PhD-avhandling, NTNU, Trondheim.

Haugan, J. A., Moen, T. \& Karlsdottir, R. (2013). Exploration of Norwegian student teachers' reflective mediation during internships. Reflective Practice, 14(2), 226-239. doi: https://doi.org/10.1080/14623943.2012.749233

Heggen, K. \& Raaen, F. D. (2014). Koherens i lærarutdanninga. Norsk Pedagogisk Tidsskrift, 98(1), 3-13.

Heggen, K. \& Smeby, J.-C. (2012). Gir mest mulig samanheng også den beste profesjonsutdanninga? Norsk Pedagogisk Tidsskrift, 96(1), 4-14.

Jahreie, C. F. \& Ottesen, E. (2010). Construction of Boundaries in Teacher Education: Analyzing Student Teachers' Accounts. Mind, Culture, and Activity, 17, 212-234. doi: https://doi.org/10.1080/10749030903314195

Jensen, A. R. (2016). Veiledningsritualet. En dialektisk studie av formaliserte veiledningssamtaler i lcererutdanningens praksisperiode. $\mathrm{PhD}$-avhandling, Universitetet i Agder, Kristiansand.

Jenset, I. S., Klette, K. \& Hammerness, K. (2018). Grounding Teacher Education in Practice Around the World: An Examination of Teacher Education Coursework in Teacher Education Programs in Finland, Norway, and the United States. Journal of Teacher Education, 69(2), 184-197. doi: https://doi.org/10.1177/002248711772824

Johannessen, A., Tufte, P. A. \& Kristoffersen, L. (2006). Introduksjon til samfunnsvitenskapelig metode. Oslo: Abstrakt Forlag.

KD (2013). Forskrift om rammeplan for lektorutdanning for trinn 8-13. Hentet fra http://www.regjeringen.no/upload/KD/Vedlegg/Rammeplanen/lektorutdanning.pdf

Klette, K. \& Hammerness, K. (2016). Conceptual Framework for Analyzing Qualities in Teacher Education: Looking at Features of Teacher Education from an International Perspective. Acta Didactica Norge, 10(2), 26-52. doi: http://dx.doi.org/10.5617/adno.2646

Kvale, S. \& Brinkmann, S. (2015). Det kvalitative forskningsintervju (3. utgave). Oslo: Gyldendal Akademisk.

Lejonberg, E. (2016). Hva kan bidra til god veiledning? En problematisering basert på veilederes og veisøkeres perspektiver på veiledning av begynnende larere. $\mathrm{PhD}-$ avhandling, Universitetet i Oslo.

Lejonberg, E., Elstad, E. \& Hunskaar, T. S. (2017). Behov for å utvikle «det tredje rom» i relasjonen mellom universitet og praksisskoler. Uniped, 40(1), 68-85. doi: https://doi.org/10.18261/ISSN.1893-8981-2017-01-06

Letelier, A. K. (2014, 1.8.). Fra Holmlia til FN. Leserinnlegg. Aftenposten. Hentet fra http://www.aftenposten.no/meninger/sid/Fra-Holmlia-til-FN-78163b.html

Lid, S. E. (2013). PPUs relevans for undervisning i skolen. En kartlegging av studenters og nyutdannede læreres oppfatninger. Nokut-rapport 2013-3, Nokuts utredninger og analyser, Oslo.

Lillejord, S. \& Børte, K. (2014). Partnerskap i læererutdanningen. En forskningskartlegging. KSU 3/2014. Oslo: Kunnskapssenter for utdanning, Norges forskningsråd. 
Ottesen, E. (2006). Talk in practice. Analysing student teachers' and mentors' discourse in internship. PhD-avhandling, Universitetet i Oslo.

Rindal, U., Lund, A. \& Jakhelln, R. (red.) (2015). Veier til fremragende lcererutdanning. Oslo: Universitetsforlaget.

Schneider, M. (2012). Knowledge Integration. I N. M. Seel (red.), Encyclopedia of the Sciences of Learning (s. 1684-1686). Freiburg: Springer.

Simensen, A. M. (2007). Teaching a Foreign Language. Principles and Procedures (2nd Edition). Bergen: Fagbokforlaget.

Vestøl, J. M. (2014). Kunnskapsintegrasjon og profesjonsutvikling i lektorutdanningen. I E. Elstad \& K. Helstad (red.), Profesjonsutvikling i skolen (s. 114-130). Oslo: Universitetsforlaget.

Vestøl, J. M. (2016). Design, Integration, and Quality. Teacher Education from the Perspective of ProTed, a Norwegian Centre of Excellence in Education. Acta Didactica Norge, 10(2), 73-91. doi: http://dx.doi.org/10.5617/adno.2394

Wartofsky, M. (1973/1979). Perception, Representation, and the Forms of Action: Towards an Historical Epistemology. I M. Wartofsky (red.), Models. Representation and the Scientific Understanding (s. 188-210). Dordrecht: D. Reidel Publishing Company.

Østrem, S. (2016). Tematikken i veiledningssamtaler - forgrunn og bakgrunn. Acta Didactica Norge, 10(3), Art. 1. doi: http://dx.doi.org/10.5617/adno.2907 


\section{VEDLEGG 1}

Kunnskapsområder og samvirkeaspekter (forstørret versjon av figur 1)

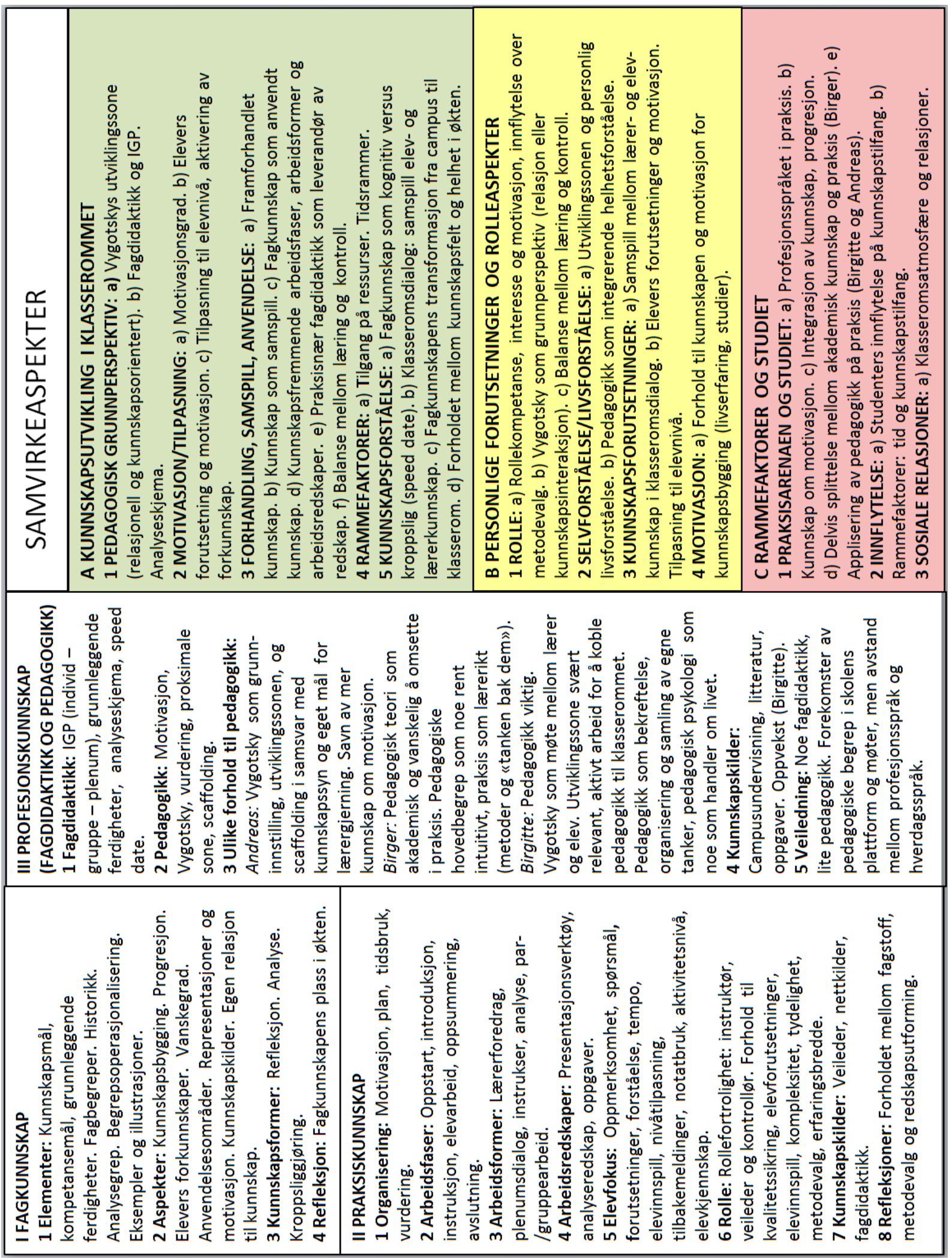

